\title{
Bacillus Subtilis as Self-Healing Agent in Cement Mortar: The Effect of Curing Time and Amount of Calcium Lactate on Strength
}

\author{
Sohail Muhammad ${ }^{1 \mathrm{a}}$, Humair Ahmed Siddiqui ${ }^{1 \mathrm{~b}}$, Muhammad Ishaque Abro , \\ Adil Usmani ${ }^{1 \mathrm{c}}$, Muhammad Amjad Anwar Malick ${ }^{1 \mathrm{~d}}$
}

\section{RECEIVED ON 20.03.2019, ACCEPTED ON 26.07.2019}

\begin{abstract}
Crack growth is a major cause of failure in structures that are made using cement and concrete. Healing of these cracks can increase the life span of structures. In the present study micro-organism based self-healing of structures is studied. A commonly occurring micro-organism bacterium called Bacillus Subtilis, is used in the manufacturing of cement mortar blocks as a self-healing agent for cement mortar blocks, with the use of Calcium Lactate as feed for bacteria. In the first step, colonies of Bacillus Subtilis were grown and added with calcium lactate to produce a solution. The solution was then kept for one week to observe the metabolic product of Bacillus Subtilis. It was found that the bacterial product was composed of $\mathrm{CaCO}_{3}$ and thus the bacteria is suitable to be used as self-healing agent. Self-healing cement mortar blocks were made by adding Bacteria and Calcium Lactate with usual ingredients of cement mortar, i.e. cement, sand and water. It was found that the bacteria were also effective in converting Calcium Lactate to Calcium Carbonate, when mixed in cement mortar blocks. It was observed that the pores of cement mortar blocks were filled by Calcium Carbonate and that cracks get healed by the deposition of Calcium Carbonate in the cracks. Cement mortar blocks, with and without healing agent, were made to compare the effect of curing time. The samples were tested after seven, fourteen and twenty-eight days to compare the effect of healing agent. All the samples with the healing agent showed a higher compressive strength in comparison with the samples that were made without healing agent. Different percentages of Calcium Lactate, ranging from 1-7\% were also used to find the best composition for future use. It was found that the compressive strength was increasing up to $5 \%$ while above $5 \%$ the increase was marginal thus it is proposed that Calcium Lactate should be used in between 5-7 \% to reduce the cost of self-healing cement in construction industry.
\end{abstract}

Keywords: Bacillus Subtilis, Crack Growth, Self-healing Agent, Calcium Lactate, Structure Failure.

\section{INTRODUCTION}

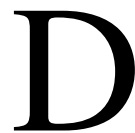
epleting natural resources along with the rapid population growth has posed a challenge for modern day researchers, to work on sustainability in every field of life especially in the construction sector. To cope up with this challenge of the construction field, research in concrete and related material has become a prime interest of the researchers, owing to its versatile nature and favorable properties [1,2]. Concrete is a vital building material that is an absolutely essential component of public infrastructure and most buildings. It will continue to be the most important building material, but most structures weaken due to cracking. Small cracks on the surface of the concrete degrade the whole structure, substantially reducing the life of the structure. Concrete can resist compressive

${ }^{1}$ Department of Materials Engineering, NED University of Engineering and Technology, Karachi, Sindh, Pakistan. Email: ${ }^{a}$ msohailhanif@neduet.edu.pk (Corresponding Author), bahumair@hotmail.com, cengineeradilusmani@gmail.com,damjad.anwar13@gmail.com

${ }^{2}$ Department of Metallurgy and Materials Engineering, Mehran University of Engineering and Technology, Jamshoro, Sindh, Pakistan. Email: ishaque.abro@ faculty.muet.edu.pk

This is an open access article published by Mehran University of Engineering and Technology, Jamshoro under CC BY 4.0 International License. 
forces very well, but not tensile. When it is subjected to tension cracks may occur that's why it is reinforced with steel to bear the tensile forces. Due to its crack healing property, it protects the reinforced steel from corrosion. Self-healing concrete helps to prevent the structure from water to relocate in to reinforced steel, prevents the structure form degradation, thus increased strength gives more durability in application [3]. Concrete structures are good in compressive strength $[2,4,5]$, but they are reinforced with steel to make them more resistant to tensile loadings, as the crack in concrete can easily grow under tensile loading conditions. Numerous methods are available to seal the cracks in concrete such as autogenous self-healing (i.e. dissolution and redisposition of hydrates) [6], mineral admixtures, which work on adding some admixture during mixing of cement/concrete that remain un-reacted. When the concrete cracks the admixture appears on the crack surface and heal the crack by reacting with water [7] the use of polymeric fillers $[8,9]$ or adhesive agents that can be applied via capsules to release the adhesive and fill the crack [10].

One of the most promising methods of self-healing of cracks is by using bacteria to self-heal the cement. The bacterial self-healing works with the addition of bacteria that must be harmless and non-pathogenic. The bacteria must be calcite producing to fill the cracks with Calcium Carbonate, when water reaches the crack $[9,11]$. The mechanism for the working of bacteria is associated with the development of crack, as once the crack developed bacteria gets activated, starts filling the crack with precipitated calcite and after filling the crack, they again go to their deactivated or hibernation state. In the future this selfhealing can be induced again, but only after the development of crack [12]. Naturally, different microorganisms can precipitate calcite [13, 14] through a biogeochemical process by chemically altering their local environment [15]. Numerous bacterial stains are used for self helaing of crack such as Bacterium Calcis, Sporosarcina Pasteurii, Bacillus Cohnii. Bacillus Halodurans and Bacillus Pseudofirmus, Shewanella anaerobic microorganisms, Bacillus Pasteurii etc. [16-22].

In this study, bacteria of the Bacillus were used, which possess exactly the accurate characteristics that could be necessary for optimum healing of micro voids. Their spores can survive in the alkaline environment for decades in a dormant state, without food or oxygen. They will become active only when water and oxygen get added in the structure. Bacillus Subtilis can produce calcite precipitates at a much faster rate, on suitable media supplemented with a calcium-based $[23,24]$. The presence of calcium-based feed in the concrete is essential to produce calcite and one of the most widely used calcium-based feed for this bacterium, is Calcium lactate. Khaliq et al. [25] studied the effect of different incorporation techniques for "Bacillus subtilis", introduced in concrete. Different incorporation techniques do affect the magnitude of crack healing and compressive strength of concrete. However, they used a large amount of $18 \%$ of calcium Lactate which would increase the cost of construction. Similarly, Vijay and Murmu [26] has used the combination of Bacillus subtilis \& calcium lactate and studied calcium lactate effect on the compressive strength cement. This study used a limited quantity of calcium lactate $(0.5-2.5 \%)$ and revealed that the higher percentages of calcium lactate may decrease the compressive strength. Irwan et al. [27] also used calcium lactate with the Bacillus Bacterium in their study of self-healing concrete and revealed the optimum level of calcium lactate, for the maximum strength. Efforts in the past were mainly focused on finding the optimum level of calcium lactate addition, which is necessary so as to reduce the overall cost of concrete, but the combined effect of curing time, the amount of bacteria and the amount of calcium lactate was not focused, moreover wide range of calcium lactate percentages were also not tested with Bacillus Subtilis.

Present study has used the Bacillus Subtilis along with the calcium lactate as a feed. The first and foremost objective of the study to induce and establish the selfhealing process, this is deemed necessary so as to prove that the cement mixture is providing the idea environment for bacteria to come out of their hibernation and start converting calcium lactate into calcium carbonate. The second objective of this study was to identify the minimum quantity of calcium lactate required for maximum strength values. 


\section{MATERIALS AND METHOD}

The Ordinary Portland Cement (OPC), Natural Sand (Fine Aggregate) and Natural Gravel (Coarse Aggregate) were procured locally and were used in as received condition. Tap water was used for making cement mortar. Bacillus Subtilis was acquired from the Microbiology Department of Karachi University. The bacterial colonies were then grown and activated by the authors. Lab grade Calcium lactate was purchased from the 'International laboratory', USA and was used without any purification. All the glasswares were thoroughly washed and dried before use. Double distilled water was used for the rest of laboratory work.

\subsection{Response of Bacillus Subtilis on Calcium Lactate}

As mentioned above, the intention was to use Calcium Lactate as a supplement to act as feed for bacteria (Bacillus Subtilis). In order to establish the response of bacteria to its feed, $3 \mathrm{gm}$ Calcium Lactate was mixed with $3 \mathrm{ml}$ of water, the solution was then heated up to $80^{\circ} \mathrm{C}$. Bacillus Subtilis colonies were added to this heated solution. The solution was then incubated for seven days after which white particles were observed, as presented through Fig. 1(a-f). These white particles were carefully collected and fine grounded for X-Ray Diffraction (XRD) analysis.

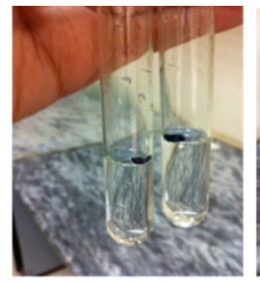

(a)

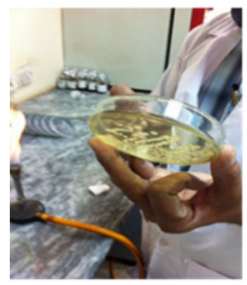

(d)

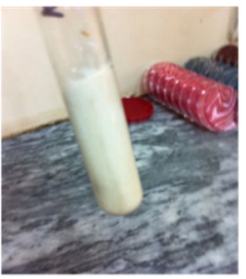

(b)

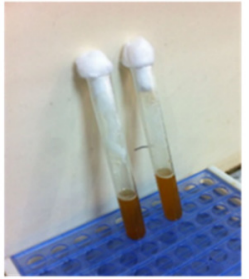

(e)

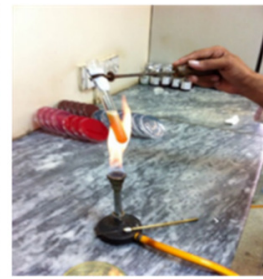

(c)

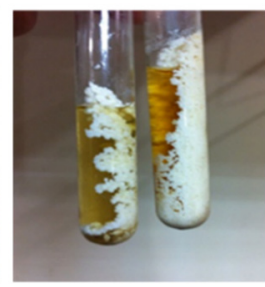

(f)
Fig. 1 (a-f): Steps in Observing the Effect of Bacillus Subtilis on Calcium Lactate

\subsection{Cement Mortar Blocks without the Healing Agent}

Simple cement mortar blocks without healing agents were produced by mixing the raw materials shown in Table1. The dry ingredients were mixed first and then the water was added to make a slurry, Fig. 2(a). PVC pipes were used as a mold to cast the blocks, (Fig. 2(b)). The samples were first kept in mold for 24 hours for drying, (Fig. 2(c)). After removing from the mold samples were immersed in the water for curing. The interrupted curing method was used, the samples were immersed in water for 15 minutes, then the samples were kept in air for one hour and then the samples were immersed in water again for 15 minutes. The process was repeated for 7 days. Compression testing was done after 7 days, 14 days and 28 days to check the strength.

\begin{tabular}{|c|c|c|}
\hline $\begin{array}{c}\text { Table 1: } \\
\text { Conventional and Microbial Self-Healing Cement } \\
\text { Mortar }\end{array}$ \\
\hline Raw Materials & $\begin{array}{c}\text { Conventional } \\
\text { Cement } \\
\text { Mortar }\end{array}$ & $\begin{array}{c}\text { Microbial } \\
\text { self-healing } \\
\text { cement } \\
\text { mortar }\end{array}$ \\
\hline Sand (75\%) & $2325 \mathrm{~g}$ & $2250 \mathrm{~g}$ \\
\hline Cement (25\%) & $775 \mathrm{~g}$ & $750 \mathrm{~g}$ \\
\hline $\begin{array}{c}\text { Calcium Lactate } \\
\text { (6\% of cement) }\end{array}$ & --- & $45 \mathrm{~g}$ \\
\hline Water & $500 \mathrm{ml}$ & $400 \mathrm{ml}$ \\
\hline \multicolumn{2}{|c}{} \\
\hline
\end{tabular}

\subsection{Cement Mortar Blocks with the Healing Agent}

Healing agent used for the cement mortar comprises of two components, first, the microorganisms (bacteria) and the feed for the bacteria. Samples with Bacteria (Bacillus Subtilis), were also manufactured in the similar fashion as that of conventional cement mortar block, Table 1, same ingredients were used but this time healing agent was added, Fig. 3(a-e). This include proper weighing of cement, sand and calcium lactate in electronic precision balance followed by dry mixing. The bacteria (Bacillus Subtilis), present in the test tube, was heated on the hot plate up to $70-80^{\circ} \mathrm{C}$, the bacteria was mixed in the dry mixture and then water was added the slurry was made. The samples were first kept in the mold for 24 hours for drying. 
After removing from the mold samples were immersed in the water for curing. The interrupted curing method as mentioned previously was used and repeated for 7 days. Compression testing was done after 7 days, 14

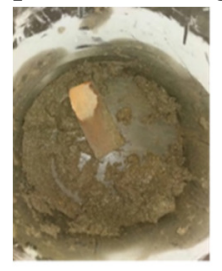

(a)

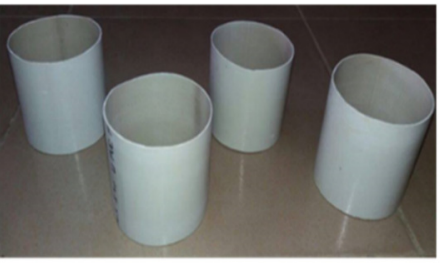

(b) days and 28 days to check the strength. Finally using the same method, the samples with Bacillus Subtilis and $1,3,5$ and $7 \%$ calcium lactate were made.

Fig. 2: Cement Mortar Block Making Procedure (a) Mixing of Ingredients, (b) PVC Pipe Sections as a Mold and (c) Cast Blocks

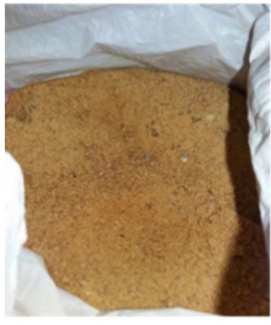

(a) Sand

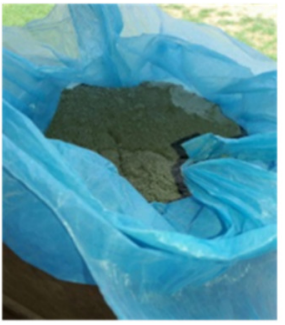

(b) Cement

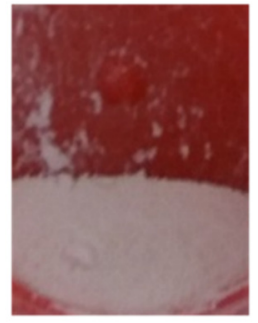

(c) Calcium Lactate

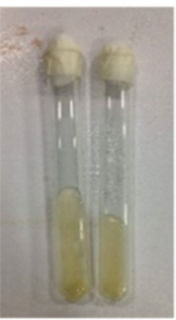

(d) Bacteria

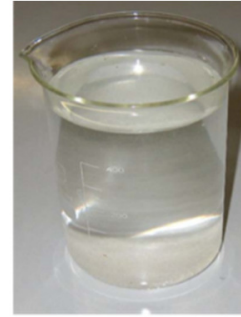

(e) Water

Fig. 3(a-e): Raw Materials used in Experiments

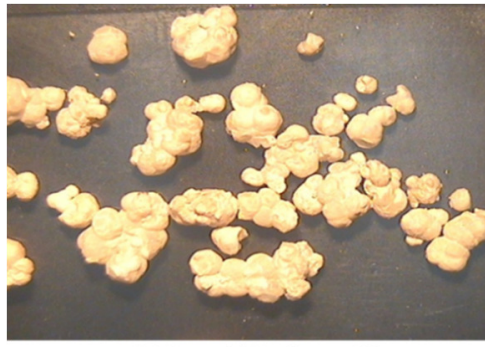

(a) Bacterial Product at $5 x$

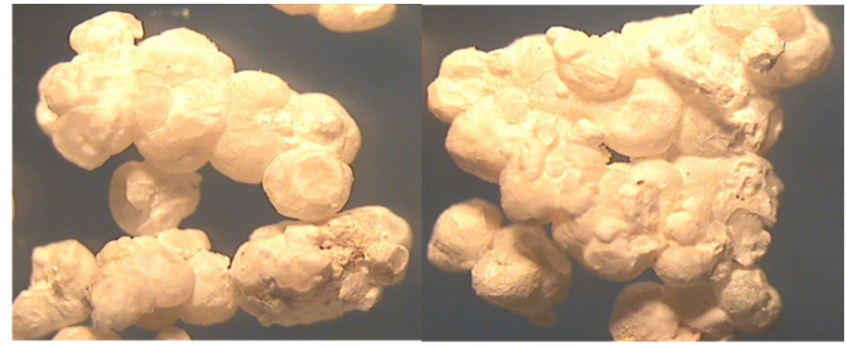

(b) Bacterial Product at 15X

Fig. 4 (a-b): Stereo Micrographs of Bacterial Product

\section{RESULTS AND DISCUSSION}

\subsection{Examination of Bacterial Product}

\subsubsection{Optical Analysis}

White substances that were produced by bacterial action after feeding with calcium lactate was examined under the stereo microscope. These white product shows dot like morphology, as shown in Fig. 4(a). At $15 \mathrm{X}$, it appears that the white dots having the same morphology are agglomerated/fused together. Also, it is indicated that these white dotted precipitates grow in the form of budding as observe in the asexual reproduction of bacteria, Fig. 4(b). These results agree well with the study by Meier et al. [28], in which calcite precipitation by the bacterium was also found to be globular white particles.

\begin{tabular}{|c|c|}
\hline \multicolumn{2}{|c|}{ Table 2: Scan Results Of XRD Test } \\
\hline Start Position [ ${ }^{\circ}$ 2Th.] & 10.0125 \\
\hline End Position [ ${ }^{\circ}$ 2Th.] & 79.9875 \\
\hline Step Size $\left[{ }^{\circ} 2 \mathrm{Th}.\right]$ & 0.0250 \\
\hline Anode Material & $\mathrm{Cu}$ \\
\hline Measurement Temperature $\left[{ }^{\circ} \mathrm{C}\right]$ & 25.00 \\
\hline Scan Type & Continuous \\
\hline
\end{tabular}

Mehran University Research Journal of Engineering and Technology, Vol. 40, No. 4, October 2021 [p-ISSN: 0254-7821, e-ISSN: 2413-7219] 


\subsubsection{Compositional Analysis}

XRD analysis was performed to confirm the composition of bacterial product. The parameters of XRD scan are summarised in Table 2.

Peaks in the XRD diffractogram, Fig. 5, matches well with the standard $\mathrm{CaCO}_{3}$ diffractogram, which confirms that the white globular calcium carbonate was precipitated. The XRD results was also compared with the study of Jing et al. [29] which clearly indicate that that the peaks were similar to the peaks of $\mathrm{CaCO}_{3}$ reported in their study. Comparison of XRD peaks with with self healing samples from Khaliq et al. [25], which contains the precipitates of $\mathrm{CaCO}_{3}$ along with the minerals found in cement, reveals that the main peak of $\mathrm{CaCO}_{3}$ was still present at $29^{\circ}$ but other peaks were also present which can be ascribed to the other minerals of cement.

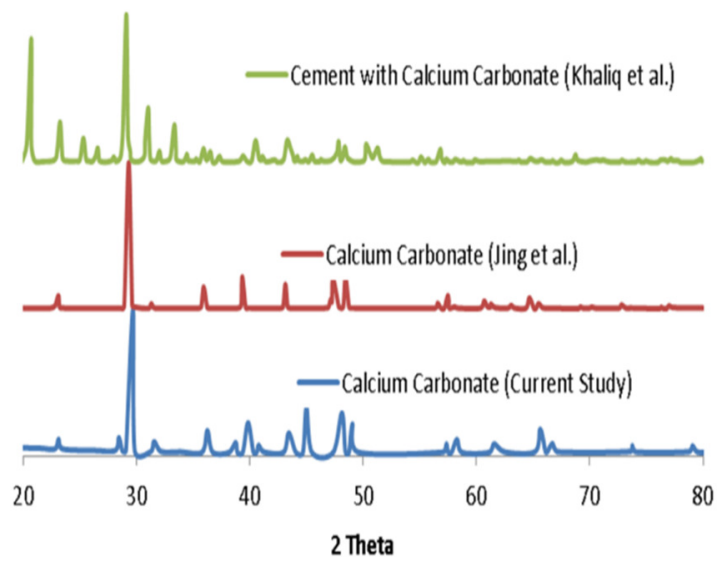

Fig. 5: XRD Pattern of Bacterial By-Product

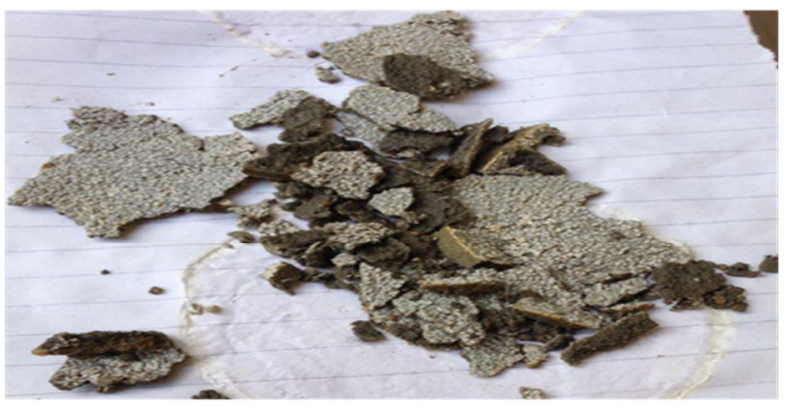

(a) Auto Removed layer on $3^{\text {rd }}$ day of curing

\subsection{Surface Appearance of Cement Mortar Blocks}

Surface appearance of cement mortar with and without is an important indication w.r.t self-healing effect. Fig. 7 (a-b) summarizes the effect of curing on the surface appearance of samples with and without healing agents. It was found that the samples without healing agent show no remarkable difference in surface appearance on the second and third day of curing, Fig. $6(a, b)$. The samples with healing agent show a remarkable change in the surface appearance. On second day of curing, Fig. 6(c), white dotted layer was observed on the top of the sample. This layer further thickened on third day of curing, Fig. 6(c, d).

Fig. 7(a) shows the product that was auto scratched out from the surface. On the fourth day of curing the layer was completely removed and the sample took the shape shown in 7 (b).

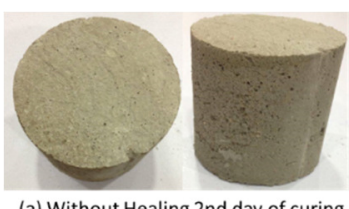

(a) Without Healing 2nd day of curing

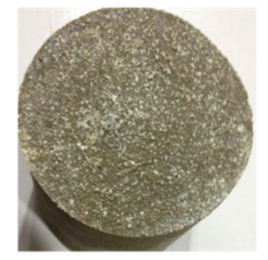

(c) With Healing 2nd day of curing

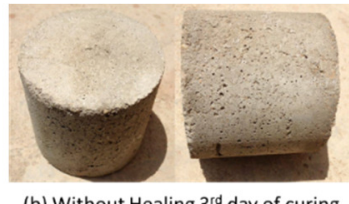

(b) Without Healing $3^{\text {rd }}$ day of curing

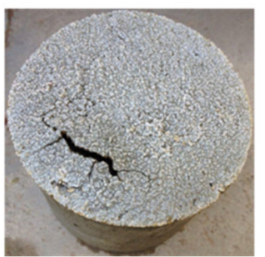

(d) With Healing $3^{\text {rd }}$ day of curing
Fig. 6: Curing Effect of Samples with and Without Healing Agent

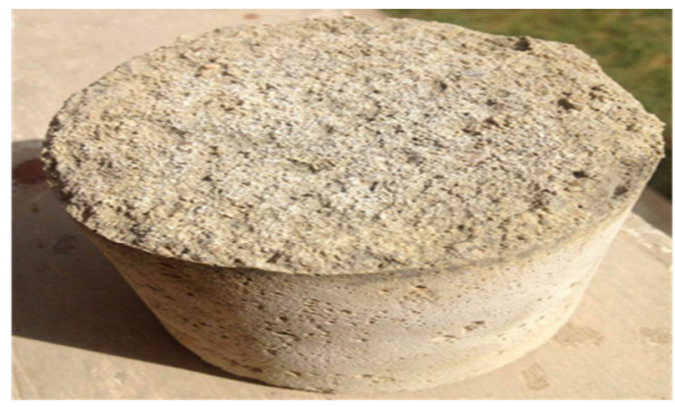

(b) With Healing $4^{\text {rd }}$ day of curing

Fig. 7: Third and Fourth Day of Curing 
A cement mortar block sample with healing agent was made containing a self-induced crack on the surface. After curing the crack appeared to be filled up/sealed, Fig. 8, due to the healing effect of bacteria.

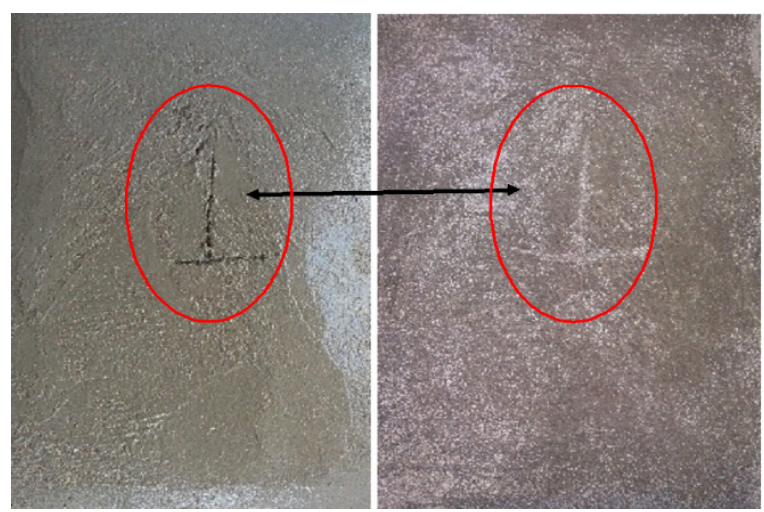

Fig. 8: Self-Induced Crack Filled Up Due to Healing

\subsection{Stereo Analysis of Scratched Layer}

Macroscopic optical analysis of auto scratched layer, Fig. 9(a-b), revealed that the layer consisted of a white precipitates on the surface which has dot like morphology. The dots were growing by interconnecting with each other. The size of dots were varying from macro to micro size. It is expected that these dots are basically the byproduct of bacteria(calcite) and have similar morphology shown in Fig. 4.

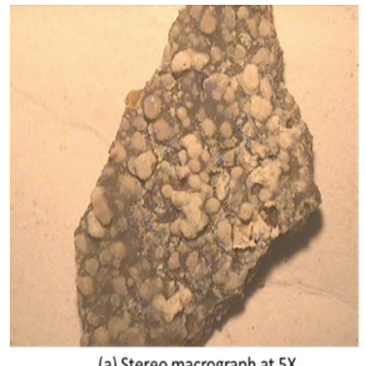

(a) Stereo macrograph at $5 x$

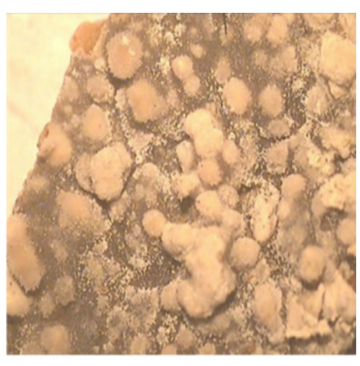

(b) Stereo macrograph at $15 \mathrm{X}$
Fig. 9(a-b): Auto Scratched Out Layer Macrographs

\subsection{Compression Testing, with and Without Healing}

Compressive strength testing of cement mortar samples was carried out different days of curing. Error! Reference source not found. summarizes the strength comparison of cement mortar samples both with and without healing agent tested on 14 and 28 days. Samples containing healing agent displayed increment in compressive strength as expected, which confirm the healing effect by Bacillus Subtilis. Samples after 7 days of curing show a lower increase in strength, Error! Reference source not found.. Table 3 summarizes the values of compressive strengths of different samples.

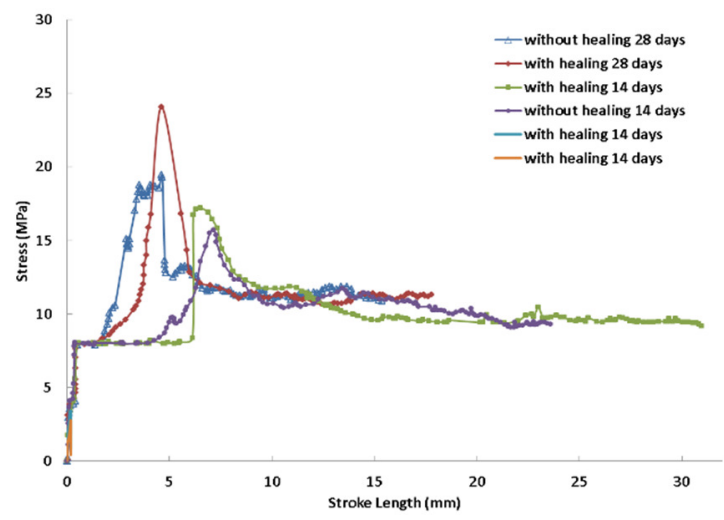

Fig. 10: Compression Testing Curves

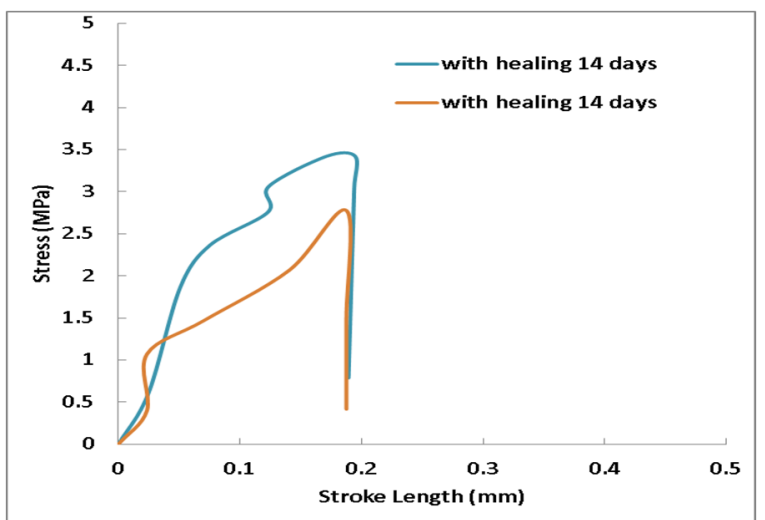

Fig. 11: Close up of 7 Days Healing

\begin{tabular}{|c|c|c|c|c|}
\hline \multicolumn{5}{|c|}{ Table 3: Comparison of Stresses } \\
\hline Samples & $\begin{array}{c}\text { Curing } \\
\text { Time }\end{array}$ & $\begin{array}{c}\text { Load } \\
\text { (kgf) }\end{array}$ & $\begin{array}{c}\text { Section } \\
\text { Area } \\
\left(\mathrm{mm}^{2}\right)\end{array}$ & $\begin{array}{c}\text { Stress } \\
(\mathrm{Mpa})\end{array}$ \\
\hline $\begin{array}{c}\text { Without } \\
\text { Healing }\end{array}$ & 7 days & 743.59 & 2617.54 & 2.79 \\
\hline $\begin{array}{c}\text { With } \\
\text { Healing }\end{array}$ & 7 days & 918.63 & 2617.54 & 3.44 \\
\hline $\begin{array}{c}\text { without } \\
\text { healing }\end{array}$ & $\begin{array}{c}14 \\
\text { days }\end{array}$ & 8882.20 & 5541.00 & 15.72 \\
\hline $\begin{array}{c}\text { with } \\
\text { healing }\end{array}$ & $\begin{array}{c}14 \\
\text { days }\end{array}$ & 9703.85 & 5541.00 & 17.17 \\
\hline $\begin{array}{c}\text { without } \\
\text { healing }\end{array}$ & $\begin{array}{c}28 \\
\text { days }\end{array}$ & 11004.10 & 5541.00 & 19.48 \\
\hline $\begin{array}{c}\text { With } \\
\text { healing }\end{array}$ & $\begin{array}{c}28 \\
\text { days }\end{array}$ & 13610.1 & 5541.00 & 24.09 \\
\hline
\end{tabular}


One of the most significant observation w.r.t. curing of sample is that addition of bacteria and calcium lactate had not produced any detrimental effect on the strength and curing cycle of concrete. This is important as usually concrete takes 28 days to fully develop its strength, so with the presence of bacteria and calcium lactate this cycle is not disturbed, moreover the strength values were also found to be increased with respect to control sample. This result agrees well with previous researches [24-26] in which self-healing concrete was found to have increased strength.

\subsection{Compression Test with Different Percentages of Calcium Lactate}

$1 \%, 3 \%, 5 \%$ and $7 \%$ Calcium lactate + Bacillus Subtilis containing samples were tested in universal testing machine for compressive test after 38 days, Fig. 12 and Table 4. It was found that the compressive strength result of $1 \%$ healing agent shows very less strength values as compared to conventional cement mortar. The compressive strength of $3 \%$ healing agent shows increased strength result due to more addition of healing agent and more calcite production in cavities. The 5\% addition of healing agent shows a more increase in compressive strength as compare to $3 \%$. The samples with $7 \%$ healing agent show only a marginal increase in compressive strength in comparison with 5\% samples although the difference with 1 and 3\% samples was considerably large, thus it is concluded that that calcium lactate percentages between $5-7 \%$ are reasonable and further increase may result in higher cost with approximately the same strength as observed in 5 and $7 \%$ healing agent. The trend of initially increasing of strength and then decreasing w.r.t. increasing parentage calcium lactate is also reported in previous researches [26, 27].

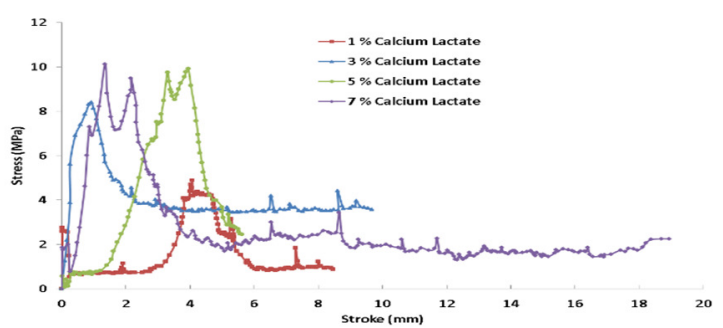

Fig. 12: Comparison of Compressive Strength for different Percentages of Calcium Lactate

\begin{tabular}{|c|c|c|c|}
\hline \multicolumn{4}{|c|}{ Table 4: Compressive Strength of different } \\
percentages
\end{tabular}

\section{CONCLUSIONS}

In a nutshell, the bacteria Bacillus Subtilis was found to be effective self-healing agent for conventional cement mortar samples, not only the Bacillus Subtilis survived in the sample, but also found to be contributing to the self-healing effect by precipitating calcite which contributed towards sealing of microvoids/cracks and enhancing compressive strength of cement mortar. This also confirms the effective role of calcium lactate as a feed for bacteria. The precipitation of calcite appeared to be fused white globules, which were hard and effective in optimizing strength of cement mortar. Compressive strength of cement mortars displaying self-healing effect was found to be as high as $24 \mathrm{MPa}$, which is a good indicator of this mortar to be used as building material. Furthermore, this research contributed towards large scale production of this unique material by analyzing the cost effectiveness i.e. increase is self-healing agent percentage is only effective up to $5 \%$ as the $7 \%$ healing agent samples show only a marginal increase in strength.

\section{ACKNOWLEDGEMENT}

The authors gladly acknowledge the NED University of Engineering and Technology, Karachi, Pakistan, for providing all the essential resources/facilities for this research.

\section{REFERENCES}

1. Ahmed M. L., Javed M. A., Qureshi A.S., "Benefits of Incorporating Induction Furnace Slag 
in Concrete as Replacement of Cement: A Case Study of Pakistan", Mehran University Research Journal of Engineering and Technology, Vol. 37, No. 4, pp. 701-714, 2018.

2. Mehmood S., Butt F., "Effect of Steel Fibers on Heat of Hydration and Mechanical Properties of Concrete Containing Fly Ash", Mehran University Research Journal of Engineering and Technology, Vol. 38, No. 1, pp. 83-94, 2019.

3. Davies R., Teall O., Pilegis M., Kanellopoulos A., Sharma T., A. Jefferson, D. Gardner, A. AlTabbaa, K. Paine, and R. Lark, "Large Scale Application of Self-Healing Concrete: Design, Construction, and Testing", Frontiers in Materials, Vol. 5, No. 51, pp. 1-12, 2018.

4. Peck M., "Concrete: Design, Construction, Examples", Basel/Berlin/Boston, Switzerland, Walter de Gruyter GmbH, 2006.

5. Peck M., "Modern Concrete Construction Manual : Structural Design, Material Properties, Sustainability", München, Germany, 2014.

6. Hearn N., "Self-sealing, autogenous healing and continued hydration: What is the difference?", Materials and Structures, Vol. 31, No. 8, p. 563, 1998.

7. Sisomphon K., Copuroglu O., Koenders E. A. B., "Self-healing of surface cracks in mortars with expansive additive and crystalline additive", Cement and Concrete Composites, Vol. 34, No. 4, pp. 566-574, 2012.

8. Davies R., Teall O., Pilegis M., Kanellopoulos A., Sharma T., Jefferson A., Gardner D., Al-Tabbaa A., Paine K., Lark R., "Large Scale Application of Self-Healing Concrete: Design, Construction, and Testing", Frontiers in Materials, Vol. 5, No. 51, 2018.

9. Huseien G. F., Shah K. W., Sam A. R. M., "Sustainability of nanomaterials based selfhealing concrete: An all-inclusive insight", Journal of Building Engineering, Vol. 23, pp. 155-171, 2019.

10. Van Tittelboom K., De Belie N., Van Loo D., Jacobs P., "Self-healing efficiency of cementitious materials containing tubular capsules filled with healing agent", Cement and Concrete Composites, Vol. 33, No. 4, pp. 497$505,2011$.
11. Sidiq A., Gravina R., Giustozzi F., "Is concrete healing really efficient? A review", Construction and Building Materials, Vol. 205, pp. 257-273, 2019.

12. Vijay K., Murmu M., Deo S. V., "Bacteria based self healing concrete - A review", Construction and Building Materials, Vol. 152, pp. 1008-1014, 2017.

13. Ehrlich H. L., "Geomicrobiology: its significance for geology", Earth-Science Reviews, Vol. 45, No. 1-2, pp. 45-60, 1998.

14. Falkowski P. G., Fenchel T., Delong E. F., "The Microbial Engines That Drive Earth's Biogeochemical Cycles", Science, Vol. 320, No. 5879, p. 1034, 2008.

15. Gerlach R., Lauchnor E., Mitchell A. C., Cunningham A. B., Spangler L., "Engineered applications of ureolytic biomineralization: a review", Biofouling, Vol. 29, No. 6, pp. 715-733, 2013.

16. Zhu, Dittrich M., "Carbonate Precipitation through Microbial Activities in Natural Environment, and Their Potential in Biotechnology: A Review", Frontiers in Bioengineering and Biotechnology, Vol. 4, No. 4, 2016.

17. Van Paassen L. Daza A., C. M., Staal M., Sorokin D. Y., van der Zon W., M. C. M. van Loosdrecht, "Potential soil reinforcement by biological denitrification", Ecological Engineering, Vol. 36, No. 2, pp. 168-175, 2010.

18. Ferris F. G., Lawson R. D., Colwell F. S., Smith R. W., "Subscribed Content Calcium Carbonate Precipitation by Ureolytic Subsurface Bacteria AU - Fujita , Y.", Geomicrobiology Journal, Vol. 17, No. 4, pp. 305-318, 2000.

19. Rodriguez-Navarro[C., Rodriguez-Gallego M., K. Ben Chekroun, and M. T. Gonzalez-Muñoz, "Conservation of Ornamental Stone by \&lt;em\&gt;Myxococcus xanthus\&lt;/em\&gt;Induced Carbonate Biomineralization", Applied and Environmental Microbiology, Vol. 69, No. 4, p. 2182, 2003.

20. Jonkers H. M., Schlangen E., "Self-healing of cracked concrete: A bacterial approach", Proceedings of the $6^{\text {th }}$ International Conference 
on Fracture Mechanics of Concrete and Concrete Structures, Vol. 3, Catania, Italy, 2007.

21. Ghosh P., Mandal S., Chattopadhyay B. D., Pal S., "Use of microorganism to improve the strength of cement mortar", Cement and Concrete Research, Vol. 35, No. 10, pp. 1980-1983, 2005.

22. Santhosh V. R., Ramachandran K., Sookie S. B., "Remediation of Concrete Using Microorganisms", Materials Journal, Vol. 98, No. 1, 2001.

23. Neeladharan C., Sharpudin J., Loganath V., Jagan B., Chinnarasu C., Vijaykaran K.R., "Application of Bacillus Subtilis Bacteria for Improving Properties and Healing of Cracks in Concrete", International Journal of Advanced Research Trends in Engineering and Technology, Vol. 5, Special Issue 5, March 2018.

24. Rathnayaka I., "Review on Self-Healing Concrete with Bacillus subtilis", Proceedings of the Annual International Sympposium, International College of Business and Technology, Sri Lanka, December 2018.

25. Khaliq W., Ehsan M. B., "Crack healing in concrete using various bio influenced self-healing techniques", Construction and Building Materials, Vol. 102, pp. 349-357, 2016.

26. Vijay K., Murmu M., "Effect of calcium lactate on compressive strength and self-healing of cracks in microbial concrete", Frontiers of Structural and Civil Engineering, Vol. 13, pp. 515-525, 2018.
27. Irwan J. M., Anneza L. H., Othman N., Alshalif A.F., Zamer M. M., Teddy T., "Calcium Lactate addition in Bioconcrete: Effect on Compressive strength and Water penetration", Proceedings of the $2^{\text {nd }}$ International Conference on Green Design and Manufacturing, MATEC Web of Conference, Vol. 78, 2016.

28. Meier A., Kastner A., Harries D., WierzbickaWieczorek M., Majzlan J., Büchel G., Kothe E., "Calcium carbonates: induced biomineralization with controlled macromorphology", Biogeosciences, Biogeosciences, Vol. 14, No. 21, pp. 4867-4878, 2017.

29. Xu J., Du Y., Jiang Z., She A., "Effects of Calcium Source on Biochemical Properties of Microbial CaCO3 Precipitation", Frontiers in Microbiology, Vol. 6, pp. 1366-1366, 2015. 